\author{
김제지역에서 비료원으로써 녹비작물과 액상우분이 수수 $\times$ \\ 수단그라스 교잡종의 생산성, 사료가치 및 토양성질에 미치는 영향 \\ 최기춘* · 나상필** · 조남철* · 정민웅* · 김종근* . 박형수* · 윤 창*** · 임영철* . 육완방**
}

\title{
Effects of Green Manure Crop and Cattle Slurry as Fertilizer \\ Sources on Productivity and Nutritive Value of Sorghum $x$ Sudangrass hybrid, and Soil Properties in Kimje, Chunlabukdo
}

Ki Choon Choi*, Sang Pil Na**, Nam Chul Jo*, Min Woong Jung*, Jong Geun Kim*, Hyung Soo Park*, Chang Yoon***, Young Chul Lim* and Wan Bang Yook**

\begin{abstract}
This study was conducted to investigate the effects of various cropping system applied with cattle slurry on productivity of sorghum $\times$ sudangrass hybrid $(\mathrm{SSH})$ and environmental pollution in paddy land. cropping systems used in this study were consisted of two designs, such as double-cropping sorghum $\times$ sudangrass hybrid followed by whole crop barley applied with cattle slurry (DSSCS) and mono-cropping sorghum $\times$ sudangrass hybrid followed by hairy vetch used as green manure (MSSGM). The field experiments were conducted on the clay loam at Backsanmyun, Kimje, Chunlabukdo province in Korea for three years (May 2006 to Apr. 2009). This study was arranged in completely randomized design with three replicates. The yield of dry matter (DM) of SSH in DSSCS increased significantly as compared with that of MSSGM $(\mathrm{P}<0.05)$. The contents of crude protein $(\mathrm{CP})$, acid detergent fiber $(\mathrm{ADF})$, neutral detergent fiber (NDF) and total digestible nutrients (TDN) of SSH were not influenced by cattle slurry and green manure. The $\mathrm{pH}$, and contents of OM, T-N and $\mathrm{P}_{2} \mathrm{O}_{5}$ in soil samples collected from DSSCS after the end of experiment were higher than those of MSSGM. The $\mathrm{pH}$, and contents of OM in DSSCS treatment were remarkably higher than those at the beginning of the experiment $(\mathrm{p}<0.05)$. However, The $\mathrm{pH}$, and contents of $\mathrm{OM}$ in MSSGM treatment were hardly influenced, as compared with those at the beginning of the experiment. The contents of T-N in soil samples collected both from DSSCS snd MSSGM treatments were remarkably higher than those at the beginning of the experiment $(\mathrm{p}<0.05)$. In addition, the concentrations of CEC in soil samples collected at the end of the experiment were remarkably higher than those at the beginning of the experiment $(\mathrm{p}<0.05)$. The concentrations of $\mathrm{NO}_{3}-\mathrm{N}, \mathrm{NH}_{3}-\mathrm{N}$ and $\mathrm{PO}_{4}-\mathrm{P}$ in leaching water were hardly influenced by the cropping system and application of cattle slurry.
\end{abstract}

(Key words : Cropping system, Sorghum $\times$ Sudangrass hybrid, Cattle slurry, Green manure, Soil property, Leaching water)

* 농촌진흥청 국립축산과학원 (National Institute of Animal Science, RDA, Seonghwan-Eup, Cheonan-Si, Chungnam, 330-801)

**건국대학교 동물생명과학대학(College of Animal Bioscience and Technology, Konkuk University, Seoul 143-701, Korea)

*** 전북대학교 동물자원과학부 (Dept. of Animal Resources and Biotechnology, Chonbuk National University, Jeonju 561-756, Korea)

Corresponding author: Dr. Wan Bang Yook, College of Animal Bioscience and Technology, Kon-Kuk University, Seoul 143-701, Korea. Tel:+82-2-450-3699. Fax:+82-2-455-1044. E-mail: wbyook@konkuk.ac.kr. 


\section{I. 서 론}

근래 수입조사료와 곡물가격의 급등으로 인 하여 자급 조사료의 중요성이 새롭게 대두되기 시작했고, 특히, 농산물 시장의 개방과 식품소 비 경향의 변화로 벼 재배 면적 감소추세와 수 입쌀의 증가로 인한 쌀 재고량 증가는 유휴논 의 발생을 증가시켜 양곡수급관리와 산지 쌀값 안정에 많은 문제점을 유발하고 있다. 조사료 의 부족과 쌀수급 불균형으로 적정 벼 재배면 적의 유지가 어려운 상황에서의 대체 작물중 수입농산물과의 경쟁에서 가장 유리한 사료작 물을 도입하여 조사료로 이용하는 것은 축산경 영비 절감측면에서 중요할 것으로 생각된다. 그리고 우리나라의 경우 가축분뇨 (연간 4,170 만톤)는 산업폐수 및 생활하수와 비교하면 매 우 적은 양이나 부유물질과 $\mathrm{BOD}$ 함량이 높아 실제로는 환경오염에 막대한 영향을 주고 있기 때문에 축분뇨의 효과적인 처리 및 활용방법에 많은 관심과 투자가 필요하게 되어 양축업자들 은 분뇨의 효과적인 처리 방안이라고 하는 커 다란 난제를 극복해야 하는 실정이다.

우리나라의 농업구조는 축산농가와 경종농가 가 분리되어 축산 농가는 분뇨처리와 조사료의 수급이, 경종농가는 화학비료와 연작에 의한 지력감퇴가 문제점으로 대두되고 있기 때문에 우리나라 경지 중 가장 많은 논에 가축분뇨를 환경 친화적으로 자원화하여 조사료 생산을 유 도하는 것은 대단히 중요하다(육 등, 1999). 또 한 최근 친환경농업과 농산물 안정성에 대한 소비자들의 관심 증가로 녹비작물의 재배면적 이 증가하고 있는데 이는 녹비작물-작물생산 - 가축-토양으로 이어지는 자연 순환적 생태 시스템으로 새로운 영역으로 다루어지기 시작 했다 (서 등, 2000a; 서 등, $2000 \mathrm{~b}$; 전 등, 2007). 논과 연계한 녹비작물과 조사료의 작부체계 를 구축하여 축산과 경종 농업을 결합, 복합 영농을 유도함으로서 식량 생산과 조사료 생산 을 동시에 해결하고 효율적인 환경보전 대책을
마련하는 것은 현시점에서 중요한 이슈이다(축 산기술연구소, 2002).

가축분뇨와 녹비작물 이용은 토양의 지력 증 진 (Freeze와 Sommerfeldt, 1985; Campbell 등, 1986; Sommerfeldt 등, 1988; 신, 1999; 조 등, 2005) 및 토양의 물리화학적 개선이나 미생물 상이 개선되어 환경농업을 유도할 수 있다 (Sommerfeldt와 Chang, 1985; Sommerfeldt와 Chang, 1987; Seo 등 1988; 전 등, 2007).

지금까지 우리나라는 밭이나 목초지에서 목 초나 사료작물의 생산성 향상을 위한 분뇨시용 량 규명에 관한 연구가 대부분 이루어졌지만 (육 등, 1999; 육, 1992ab) 답작지대에서 녹비작 물과 가축분뇨의 이용성 측면에서 다양한 연구 가 이루어 지지 않고 있다. 최근 정부의 조사 료 확대생산 계획 (2007년)에 따라 재배면적이 다소 증가할 것으로 예상되고 있으며 또한 우 리는 조사료를 생산할 수 있는 충분한 토지기 반 잠재력 즉, 논을 이용한 이모작 답리작 사 료작물 생산이 가능하다. 지금까지 답리작에 많이 재배되고 있는 사료작물은 호밀과 이탈리 안 라이그라스이며 (고 등, 1991; 채 등, 1995; 진 등, 1996; 조 등, 2008), 최근 보리를 총체상 태에서 수확하여 가축의 조사료로 이용하는 농 가가 증가하고 있다 (김 등, 2007). Hairston 등 (1987)은 2모작 작부체계를 하는 것은 토지를 효율적으로 이용하여 경제적 소득을 높이기 위 해서라고 하였으며, 또한 이모작은 단작에 비 해 토지, 노동력 및 기계장비의 이용효율을 올 릴 수 있다고 하였다.

현재 우리나라에서는 답작지대에서 사료작물 재배시 녹비작물 및 우분뇨의 처리형태에 따른 환경친화적 자원화를 위한 방안이 설정되어 있 지 않을 뿐더러 우리나라의 기후풍토는 외국과 는 현저히 달라 외국의 자료 (Jarvis 등, 1987; Hariston 등, 1987; Long과 Gracey, 1990; Gilley 등, 1999)를 그대로 적용 할 경우 많은 문제점 을 야기시킬 수 있기 때문에 우리의 조건에 맞 는 답리작 우분뇨 처리방법 및 녹비작물의 자 
원화를 위한 효율적인 이용방법에 대한 연구가 필수적으로 수행되어야 한다.

따라서 본 연구에서는 조사료자원으로써 답 작지대에서 녹비작물과 액상우분 시용이 수수× 수단그라스 교잡종의 생산성과 사료가치 및 토 양환경에 미치는 영향을 조사하였으며 또한 답 작지대에서 수질환경오염 방지 대책을 위한 우 분슬러리의 시용효과를 제시하고자 수행하였다.

\section{ㅍ. 재료 및 방법}

본 시험은 전라북도 김제군에 소재한 농경지 에서 2006년 4월부터 2009년 4월까지 3년 동안 수행하였으며 공시토양의 성분은 Table 1 그리고 기후적인 상황은 Fig. 1과 같다. 그리고 우분액비 는 김제시 백산면 시험포 부근에 위치한 착유우 목장에서 6개월 동안 완전 부숙시킨 슬러리를 이용하였으며, 매 시용시기 마다 정기적으로 시 료를 채취하여 성분을 분석한 다음 시용수준을 결정하였다(Table 2). 우분액비 시용은 파종 전 에 전량 시용하였다. 본 시험에 사용된 수수 $\times$ 수 단그라스 교잡종은 Sordan 79를 그리고 헤어리베 치는 Oregon common 품종을 이용하였다.

논에서의 수수x수단그라스 교잡종을 생산하 기 위해 시험구의 배치는 총체보리 후작물로써 수수×수단그라스 교잡종 우분액비 $100 \%$ 시험 구 (우분액비구/이모작구) 그리고 헤어리베치를 녹비작물로 이용한 다음 후작물로써 수수x수단 그라스 교잡종 시험구(일모작구)로 하였다. 시 험구 면적은 시험구당 $333 \mathrm{~m}^{2}$ (100평)로 완전임 의 배치 3 반복으로 배치하였다. 수수수단그라
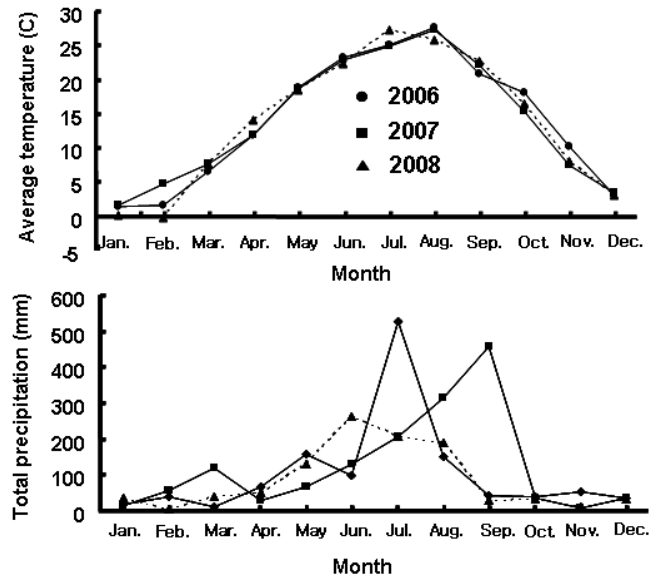

Fig. 1. Meterological information during the experimental periods.

스 교잡종 $\left(\mathrm{P}_{2} \mathrm{O}_{5}: 150, \mathrm{~K}_{2} \mathrm{O}: 150\right)$ 의 경우, 질소는 $\mathrm{N}$ 기준으로 우분액비 $200 \mathrm{~kg} / \mathrm{ha}$ 을 공급하였으 며, 인산 $\left(\mathrm{P}_{2} \mathrm{O}_{5}: 150\right)$ 과 가리 $\left(\mathrm{K}_{2} \mathrm{O}: 150\right)$ 는 기비로 서 전량 시용하였다. 수수 $\times$ 수단그라스 교잡종 은 6월 초순 그리고 헤어리베치는 9월 말경에 각각 파종하였다. 그리고 총체보리 재배시 우 분액비 $(150 \mathrm{Nkg} / \mathrm{ha})$ 는 기비 $50 \%(10$ 월 하순 $)$ 와 추비 (이른봄 3 월 중순)로 나누어서 시용하였으 며 생산량은 2 년 평균 $851 \mathrm{~kg} / 10 \mathrm{a}(\mathrm{DM})$ 을 나타 냈다. 그리고 녹비작물인 헤어리베치는 지속적 으로 녹비로 이용하였으며 생산량은 2 년 평균 $355 \mathrm{~kg} / 10 \mathrm{a}(\mathrm{DM})$ 을 나타냈다. 시비, 제초, 병충 해 방제 등의 포장관리는 농가의 관행적인 방 법으로 수행하였다.

수수×수단그라스 교잡종의 생산성은 관행에 의하여 적기에 수확하고 생초량을 측정하였으 며, 그 중 일부를 채취 칭량한 후 $70^{\circ} \mathrm{C}$ 건조기

Table 1. Properties of soil collected at beginning of experiment in paddy land

\begin{tabular}{|c|c|c|c|c|c|c|c|c|}
\hline \multirow{2}{*}{ Items } & \multirow{2}{*}{$\begin{array}{c}\mathrm{pH} \\
\left(1: 5 \mathrm{H}_{2} \mathrm{O}\right) \\
\end{array}$} & \multirow{2}{*}{$\begin{array}{c}\text { Avail. } \mathrm{P}_{2} \mathrm{O}_{5} \\
(\mathrm{mg} / \mathrm{kg})\end{array}$} & \multirow{2}{*}{$\begin{array}{c}\mathrm{OM}^{3)} \\
(\%)\end{array}$} & \multirow{2}{*}{$\begin{array}{l}\left.\mathrm{T}-\mathrm{N}^{4}\right) \\
(\%)\end{array}$} & \multicolumn{4}{|c|}{ Exchangeable cations $\left(\mathrm{cmol}^{+} / \mathrm{kg}\right)$} \\
\hline & & & & & $\mathrm{Ca}^{2+}$ & $\mathrm{K}$ & $\mathrm{Mg}$ & $\mathrm{Na}$ \\
\hline $\operatorname{DSSCS}^{1)}$ & 5.04 & 105.83 & 3.10 & 0.16 & 2.14 & 0.16 & 1.02 & 0.15 \\
\hline MSSGM $^{2)}$ & 4.97 & 94.56 & 3.31 & 0.21 & 2.15 & 0.18 & 1.13 & 0.16 \\
\hline
\end{tabular}

${ }^{1)}$ DSSCS : double-cropping sorghum $\times$ sudangrass hybrid following whole crop barley applied with cattle slurry and ${ }^{2)}$ MSSGM : mono-cropping sorghum $\times$ sudangrass hybrid following hairy vetch applied with cattle slurry.

${ }^{3)} \mathrm{OM}$ : organic matter, ${ }^{4)} \mathrm{T}-\mathrm{N}$ : Total nitrogen. 
Table 2. Major properties of cattle slurry used in this experiment

\begin{tabular}{cccccccc}
\hline Year & $\begin{array}{c}\text { Moisture } \\
(\%)\end{array}$ & $\begin{array}{c}\mathrm{N} \\
(\%)\end{array}$ & $\begin{array}{c}\mathrm{P}_{2} \mathrm{O}_{5} \\
(\%)\end{array}$ & $\begin{array}{c}\mathrm{K}_{2} \mathrm{O} \\
(\%)\end{array}$ & $\begin{array}{c}\mathrm{CaO} \\
(\%)\end{array}$ & $\begin{array}{c}\mathrm{MgO} \\
(\%)\end{array}$ & $\begin{array}{c}\mathrm{Na}_{2} \mathrm{O} \\
(\%)\end{array}$ \\
\hline \hline 2006 & 92.10 & 0.52 & 0.24 & 0.39 & 0.24 & 0.13 & 0.13 \\
2007 & 90.10 & 0.55 & 0.44 & 0.44 & 0.42 & 0.20 & 0.21 \\
2008 & 92.30 & 0.52 & 0.43 & 0.42 & 0.40 & 0.20 & 0.21 \\
\hline Mean & 91.50 & 0.53 & 0.37 & 0.42 & 0.35 & 0.18 & 0.18 \\
\hline
\end{tabular}

에서 48시간 건조 후 건물 생산량을 산출하였 다. 비료원으로써 녹비작물과 액비시용에 따른 수수×수단그라스 교잡종의 사료가치를 조사하 기 위해 채취된 시료를 건조하여 $20 \mathrm{mesh}$ 의 Wiley mill로 분쇄하여 실험실내 desiccator에 보관하였다가 Kjeldahl 정량법으로 조단백질 함 량(AOAC, 1993)을, NDF 및 $\mathrm{ADF}$ 함량은 Van Soest법 (1970)에 의해 분석하였다. TDN은 TDN $=4.898+(89.796 \times \mathrm{NEL}), \quad \mathrm{NEL}=0.7936-(0.00344$ $\times \mathrm{ADF})$ 에 의하여 계산하였다(김 등, 2009).

우분액비 시용에 따른 답리작 토양성분 (시험 전후)은 이앙 후 논 토양의 표토를 채취하여 실내에서 자연 건조한 다음 이를 잘 마쇄하여 토양분석법(농촌진흥청, 1989)에 준하여 분석 하였다.

녹비작물 및 우분액비에 따른 양분의 용탈량 에 대한 조사는 수도작 지대의 적절한 지역에 무작위로 3 개 이상의 suction cup을 깊이 $1 \mathrm{~m}$ 에 설치하고 FIAStar 5000 Analyzer (Foss Tecator, Sweden)를 이용하여 $\mathrm{NO}_{3}-\mathrm{N}, \mathrm{NH}_{4}-\mathrm{N}$ 및 $\mathrm{PO}_{4}-\mathrm{P}$ 의 농도를 측정하였다. 본 시험에서 얻은 모든 결 과는 Windows 용 SPSS/PC (Statistical Package for the Science, ver 12.0. USA) 통계프로그램을
이용하여 T-test $(\mathrm{p}<0.05)$ 로 분석하였다 (SPSS Inc, 1968).

\section{III. 결과 및 고찰}

\section{1. 수수 $\times$ 수단그라스 교잡종의 수량}

우분액비를 이용한 총체보리+수수×수단그라 스 교잡종 이모작 그리고 헤어리베치를 녹비작 물로 사용한 후 수수x수단그라스 교잡종 일모 작으로 재배했을 때 수수 $\times$ 수단그라스 교잡종의 건물수량은 Table 3 과 같다. 수수 $\times$ 수단그라스 교잡종의 건물수량은 이모작 및 일모작 모두 재배 첫해에 가장 높은 수량을 보였으며 $(\mathrm{p}<$ $0.05)$ 연차적으로 현저하게 감소되는 경향을 보 였다. 그리고 이모작의 경우가 헤어리 베치를 이용한 일모작에 비해 건물수량이 현저하게 증 가하였다 $(\mathrm{p}<0.05)$.

\section{2.사료가치}

수수 $\times$ 수단그라스 교잡종은 총체보리와 이모 작의 경우와 헤어리베치를 녹비작물로 이용한

Table 3. Effect of green manure crop and cattle slurry as fertilizer sources on dry matter $(\mathrm{DM})$ yield of sorghum $\times$ sudangrass hybrid in paddy land

\begin{tabular}{lrrrc}
\hline \multirow{2}{*}{ Treatment } & \multicolumn{4}{c}{ Year $(\mathrm{kg} / 10 \mathrm{a})$} \\
\cline { 2 - 5 } & 2006 & 2007 & 2008 & Mean \\
\hline \hline DSSCS $^{1)}$ & $1,141 \mathrm{a}$ & $974 \mathrm{a}$ & $772 \mathrm{a}$ & $962 \mathrm{a}$ \\
MSSGM $^{2)}$ & $890 \mathrm{~b}$ & $398 \mathrm{~b}$ & $425 \mathrm{~b}$ & $571 \mathrm{~b}$ \\
\hline
\end{tabular}

$a$ and $b$ : Means with different letters within a column are significantly different at the $5 \%$ level.

${ }^{1)}$ DSSCS: double-cropping sorghum $\times$ sudangrass hybrid following whole crop barley applied with cattle slurry and ${ }^{2)}$ MSSGM: mono-cropping sorghum $\times$ sudangrass hybrid following hairy vetch applied with cattle slurry. 
일모작의 경우 각각의 3 년 평균 수수 $\times$ 수단그 라스 교잡종의 조단백질 함량은 $5.52,5.71 \%$, $\mathrm{NDF}$ 함량은 $72.98,73.97 \%, \mathrm{ADF}$ 함량은 46.13, $48.21 \%$ 및 $\mathrm{TDN}$ 함량은 $52.44,50.90 \%$ 로 처리 구간에 큰 차이는 나타나지 않았다 (Table 4).

일반적으로 두과작물인 헤어리베치는 옥수수 재배 시 화학비료 절감이 가능하다고 보고(Seo 등, 1998) 하고 있으나 본 연구의 결과에서 나 타낸바와 같이 답리작에서 녹비작물을 이용해 수수×수단그라스 교잡종을 재배할 경우 많은 수량감소를 보이기 때문에 반드시 추가적인 화 학비료나 가축분뇨가 필요할 것으로 생각된다.

총체보리 후작으로 들어간 수수x수단그라스 교잡종 그리고 헤어리베치를 녹비작물로 이용 한 후 후작으로 들어간 수수x수단그라스 교잡 종의 수량간에는 큰 차이를 나타냈으나 사료가 치는 크게 차이가 나타나지 않았다. 그리고 전 작에서의 수량과 답작지의 전작물과 후작물의 수량이 차이가 크게 발생되고 있는데 이는 우 분액비를 시용한 다음 질소원의 휘산이나 다량 의 강우가 왔을 때 배수불량에 의한 생육불량 그리고 재배지의 특성상 다량의 강우시 배수로 인하여 우분액비 내 주요 비료원이 밖으로 배 출되었기 때문인 것으로 보이기 때문에 추후 다양한 접근을 통한 답리작에서의 사료작물에
대한 연구가 반드시 필요할 것으로 생각된다.

\section{3. 토양의 이화하성분}

시험전과 시험종료 후의 토양이화학적 성분 은 Table 5와 같다. 총체보리+수수×수단그라스 교잡종 이모작구 그리고 헤어리베치를 녹비작 물 이용한 수수 $\times$ 수단그라스 교잡종 일모작구 모두에서 시험 전보다 시험 종료 후에 전질소 및 양이온치환용량 $\left(\mathrm{Ca}^{2+}, \mathrm{K}, \mathrm{Mg}, \mathrm{Na}\right)$ 은 현저하 게 증가하는 경향을 보여주었다 $(\mathrm{P}<0.05)$. 총체 보리+수수 $\times$ 수단그라스 교잡종 이모작구의 토양 $\mathrm{pH}$ 및 토양유기물 함량은 시험 종료 후에 현 저한 증가 $(\mathrm{P}<0.05)$ 를 나타냈으나, 헤어리베치를 녹비작물 이용한 수수×수단그라스 교잡종 일모 작구에서는 차이가 나타나지 않았다.

이상의 결과에서 보는 바와 같이 우분액비 시용에 따라 토양 내 유기물, 전질소, $\mathrm{Ca}^{2+}$, $\mathrm{Mg}, \mathrm{Na}$ 및 $\mathrm{Na}$ 의 농도는 현저하게 증가하였는 데 이는 우분내의 무기성분, 전작물과 후작물 의 지하부가 토양 내에서 토착미생물에 의해서 부숙되면서 무기성분이 증가되었기 때문인 것 으로 생각된다. 또한 토양 내 무기함량의 차이 는 전작물의 종류 및 작부체계에 의한 작물의 토양 내 성분의 이용차이에 기인된 것으로 생

Table 4. Effect of green manure crop and cattle slurry as fertilizer sources on the nutritive values of sorghum $\times$ sudangrass hybrid in paddy land.

\begin{tabular}{clrrrr}
\hline \multirow{2}{*}{ Items } & \multirow{2}{*}{ Treatment } & \multicolumn{4}{c}{ Year } \\
\cline { 3 - 6 } & & 2006 & 2007 & 2008 & Mean \\
\hline \hline \multirow{2}{*}{ CP (\%) } & DSSCS $^{1)}$ & 5.4 & 5.33 & 5.83 & 5.52 \\
\cline { 2 - 5 } & MSSGM $^{2)}$ & 5.7 & 5.74 & 5.69 & 5.71 \\
\hline \multirow{2}{*}{ NDF (\%) } & DSSCS & 72.5 & 77.06 & 69.39 & 72.98 \\
\cline { 2 - 6 } & MSSGM & 72.7 & 78.11 & 71.1 & 73.97 \\
\hline \multirow{2}{*}{ ADF (\%) } & DSSCS & 47.70 & 45.96 & 44.74 & 46.13 \\
\cline { 2 - 5 } & MSSGM & 49.40 & 48.21 & 47.03 & 48.21 \\
\hline \multirow{2}{*}{ TDN (\%) } & DSSCS & 51.20 & 52.59 & 53.55 & 52.45 \\
\cline { 2 - 5 } & MSSGM & 49.80 & 51.14 & 51.75 & 50.90 \\
\hline
\end{tabular}

a and $b$ : Means with different letters within a column are significantly different at the $5 \%$ level

${ }^{1)}$ DSSCS: double-cropping sorghum $\times$ sudangrass hybrid following whole crop barley applied with cattle slurry and ${ }^{2)}$ MSSGM: mono-cropping sorghum $\times$ sudangrass hybrid following hairy vetch applied with cattle slurry. 
Table 5. Effect of green manure crop and cattle slurry as fertilizer sources on the characteristics of soil collected at the end of experiment in paddy land

\begin{tabular}{|c|c|c|c|c|c|c|c|c|c|}
\hline \multirow{2}{*}{ Items } & \multirow{2}{*}{ Experiment } & \multirow{2}{*}{$\mathrm{pH}$} & \multirow{2}{*}{$\begin{array}{c}\text { Avail. } \\
\mathrm{P}_{2} \mathrm{O}_{5} \\
(\mathrm{mg} / \mathrm{kg}) \\
\end{array}$} & \multirow{2}{*}{$\begin{array}{c}\mathrm{OM}^{5)} \\
(\%)\end{array}$} & \multirow{2}{*}{$\begin{array}{c}\left.\mathrm{T}-\mathrm{N}^{6}\right) \\
(\%)\end{array}$} & \multicolumn{4}{|c|}{ Exchangeable cations $\left(\mathrm{cmol}^{+} / \mathrm{kg}\right)$} \\
\hline & & & & & & $\mathrm{Ca}^{2+}$ & $\mathrm{K}$ & $\mathrm{Mg}$ & $\mathrm{N}$ \\
\hline \multirow{2}{*}{$\operatorname{DSSCS}^{1)}$} & Before $^{3)}$ & $5.04 \mathrm{~b}$ & $105.83 \mathrm{a}$ & $3.10 \mathrm{~b}$ & $0.16 \mathrm{~b}$ & $2.14 \mathrm{~b}$ & $0.16 \mathrm{~b}$ & $1.02 \mathrm{~b}$ & $0.15 b$ \\
\hline & After $^{4)}$ & $6.05 \mathrm{a}$ & $98.65 \mathrm{a}$ & $3.78 \mathrm{a}$ & $0.26 \mathrm{a}$ & $6.12 \mathrm{a}$ & $0.67 \mathrm{a}$ & $2.37 \mathrm{a}$ & $0.36 \mathrm{a}$ \\
\hline \multirow{2}{*}{ MSSGM $^{2)}$} & Before & $4.97 \mathrm{a}$ & $94.56 \mathrm{a}$ & $3.32 \mathrm{a}$ & $0.16 b$ & $2.15 b$ & $0.18 b$ & $1.13 \mathrm{a}$ & $0.16 \mathrm{~b}$ \\
\hline & After & $5.40 \mathrm{a}$ & $78.52 b$ & $3.35 \mathrm{a}$ & $0.20 \mathrm{a}$ & $4.58 \mathrm{a}$ & $0.37 \mathrm{a}$ & $1.75 \mathrm{a}$ & $0.32 \mathrm{a}$ \\
\hline
\end{tabular}

$\mathrm{a}$ and $\mathrm{b}$ : Means with different letters within a column are significantly different at the $5 \%$ level.

${ }^{3)}$ Before: Characteristics of soil collected at beginning of experiment in paddy land (2006).

4) After: Characteristics of soil collected at the end of experiment in paddy land (2009).

${ }^{1)}$ DSSCS: double-cropping sorghum $\times$ sudangrass hybrid following whole crop barley applied with cattle slurry and ${ }^{2)}$ MSSGM: mono-cropping sorghum $\times$ sudangrass hybrid following hairy vetch applied with cattle slurry.

5) $\mathrm{OM}$ : organic matter, ${ }^{6)} \mathrm{T}-\mathrm{N}$ : Total nitrogen.

각된다.

따라서 논토양에서 우분액비와 지하부의 부 숙관계에 있어서 무기성분의 변화에 관한 또 다른 측면에서 많은 연구가 진행되어야 할 것 으로 생각된다.

\section{4. 논의 용탈수중 $\mathrm{NO}_{3}-\mathrm{N}, \mathrm{NH}_{4}-\mathrm{N}$ 및 $\mathrm{PO}_{4}-\mathrm{P}$ 의 농도 변화}

경작형태별 우분액비 시용이 환경오염에 미 치는 영향을 파악하기 위하여 $\mathrm{NO}_{3}-\mathrm{N}, \mathrm{NH}_{4}-\mathrm{N}$ 및 $\mathrm{PO}_{4}-\mathrm{P}$ 의 용탈을 suction cup을 지하 $1 \mathrm{~m}$ 깊 이로 설치하여 일정간격으로 조사한 결과는 Fig. 2, 3 및 4 와 같다.

경작형태별 우분액비 시용에 따른 평균적인 $\mathrm{NO}_{3}-\mathrm{N}$ 및 $\mathrm{NH}_{4}-\mathrm{N}$ 농도는 Fig. 2 및 3 에서와 같 이 경작형태에 따른 확실한 차이를 보여주지 않았고, 단지 우분액비 시용초기에 약 $1-3 \mathrm{mg} / \mathrm{L}$ 정도로 용탈됨을 알 수 있었다.

또한 경작형태별 우분액비 시용에 따른 평균 적인 $\mathrm{PO}_{4}-\mathrm{P}$ 농도도 Fig. 4 에서와 같이 $\mathrm{NO}_{3}-\mathrm{N}$ 및 $\mathrm{NH}_{4} \mathrm{-N}$ 농도변화와 유사하게 경작형태에 따 른 확실한 차이를 보여주지 않았고, 단지 우분 액비 시용초기에 약 $0.01 \sim 0.02 \mathrm{mg} / \mathrm{L}$ 정도로 용 탈됨을 알 수 있었다.

이상의 결과에서 나타난바와 같이 경작형태

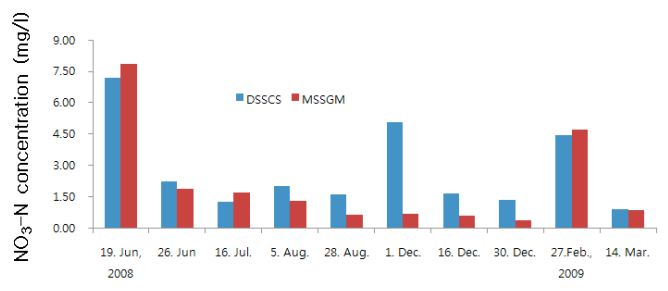

Fig. 2. The level of $\mathrm{NO}_{3}-\mathrm{N}$ in leaching water from paddy land by green manure crop and cattle slurry as fertilizer sources during the experimental period. DSSCS: doublecropping Sorghum $\times$ Sudan hybrid following wholecrop barley applied with cattle slurry and MSSGM: monocropping Sorghum $\times$ Sudan hybrid following betch applied with cattle slurry.

별 우분액비 시용에 따른 용탈수중 $\mathrm{NO}_{3}-\mathrm{N}$, $\mathrm{NH}_{4}-\mathrm{N}$ 및 $\mathrm{PO}_{4} \mathrm{P}$ 농도는 계절에 관계없이 일정 한 경향을 유지하는 것을 알 수 있었다. 일반 적으로 전작지에서는 계절적으로는 강수량에 따라 강수량이 많았던 8월 하순에 용탈수중 $\mathrm{NO}_{3}-\mathrm{N}, \mathrm{NH}_{4}-\mathrm{N}$ 및 $\mathrm{PO}_{4}-\mathrm{P}$ 농도가 증가한다고 최 등 (2008)은 보고하고 있는데, 본 연구의 결과 와 상이한 결과를 나타낸 이유는 전작지와 답 작지역에서의 경작형태가 다르기 때문인 것으 로 생각된다. 따라서 답작지와 전작지에서의 양분용탈에 관한 새로운 학문적 접근이 이루어 져야할 것으로 생각되며 또한 수질환경보존차 


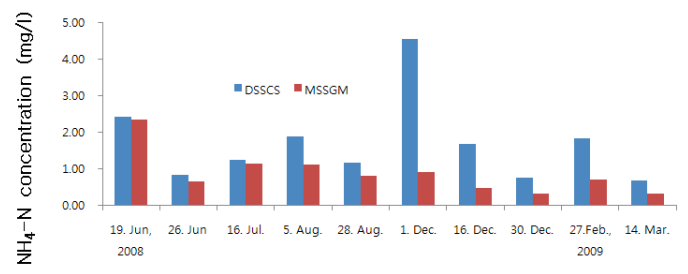

Fig. 3. The level of $\mathrm{NH}_{4}-\mathrm{N}$ in leaching water from paddy land by green manure crop and cattle slurry as fertilizer sources during the experimental period. DSSCS: double-cropping sorghum $\times$ sudangrass hybrid following whole crop barley applied with cattle slurry and MSSGM: mono-cropping sorghum $x$ sudangrass hybrid following hairy vetch applied with cattle slurry.

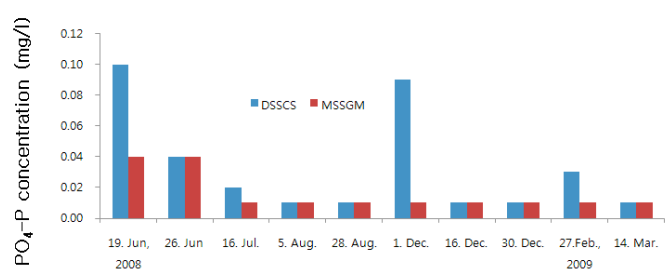

Fig. 4. The level of $\mathrm{PO}_{4}-\mathrm{P}$ in leaching water from paddy land by green manure crop and cattle slurry as fertilizer sources during the experi- mental period. DSSCS: double -cropping sorghum $\times$ sudangrass hybrid following whole crop barley applied with cattle slurry and MSSGM: monocropping sorghum×sudangrass hybrid following hairy vetch applied with cattle slurry.

원에서도 전작과 답작의 작부체계에 관한 분뇨 이용시스템 구축이 필요하다고 생각된다.

\section{IV. 요 약}

본 연구에서는 논에서의 조사료 생산을 위한 작부형태별 우분액비의 시용효과를 규명하기 위하여 총체보리+수수x수단그라스 교잡종 이모 작구 그리고 헤어리베치를 녹비작물로 이용한 후 수수×수단그라스 교잡종 일모작구로 하여 논에서의 다양한 조사료 작부 형태를 배치하 고, 수수x수단그라스 교잡종의 생산성 및 사료
가치를 조사하였다. 그리고 처리구별 토양의 지력증진 효과를 분석함과 동시에 우분액비의 시용과 경작형태에 따른 용탈수중 $\mathrm{NO}_{3}-\mathrm{N}$, $\mathrm{NH}_{4}-\mathrm{N}$ 및 $\mathrm{PO}_{4}-\mathrm{P}$ 등을 분석하여 환경오염에 미 치는 영향을 조사하였다. 본 연구는 수수x수단 그라스 교잡종의 생산성과 환경에 미치는 영향 을 평가하고자 2006년 5월부터 2009년 4월 까 지 3년 동안 전라북도 김제군 백산면 시험포장 에서 완전임의배치 3 반복으로 수행되었다. 수 수x수단그라스 교잡종은 총체보리와 이모작의 경우가 헤어리베치를 이용한 일모작에 비해 수 량이 현저하게 증가하였다 $(\mathrm{P}<0.05)$. 그리고 수 수 $\times$ 수단그라스 교잡종의 조단백질, $\mathrm{NDF}, \mathrm{ADF}$ 및 TDN 함량은 처리구간에 큰 차이는 나타나 지 않았다. 총체보리와 이모작구에서의 $\mathrm{OM}$, $\mathrm{T}-\mathrm{N}$ 및 $\mathrm{P}_{2} \mathrm{O}_{5}$ 함량은 녹비작물로 이용된 일모 작구에 비해 높았다. 그리고 우분액비시용에 따른 토양 내 $\mathrm{pH}$ 와 $\mathrm{OM}$ 농도는 시험전에 비해 시험종료 후에 현저하게 증가하는 경향을 나타 냈다. 또한 이모작구와 일모작구에서 T-N 함량 은 시험전에 비해 시험종료 후에 현저하게 증 가하는 경향을 나타냈다 $(\mathrm{P}<0.05)$. 경작형태별 우분액비 시용에 따른 토양내 양이온치환용량 $\left(\mathrm{Ca}^{2+}, \mathrm{K}, \mathrm{Mg}\right.$ 및 $\left.\mathrm{Na}\right)$ 농도는 시험 전에 비해 시험종료 후에 현저하게 증가하는 경향을 나타 냈다 $(\mathrm{P}<0.05)$. 또한 경작형태별 우분액비 시용 에 따른 용탈수중 $\mathrm{NO}_{3}-\mathrm{N}, \mathrm{NH}_{4}-\mathrm{N}$ 및 $\mathrm{PO}_{3}-\mathrm{P}$ 의 농도는 경작형태에 따른 확실한 차이를 보여주 지 않았다.

\section{V. 인 용 문 헌}

1. 고영두, 정길영, 류영우, 김두환, 김재황. 1991. 파종시기와 파종방법이 답리작 Italian ryegrass의 월동력과 수량에 미치는 영향. 한국초지조사료학 회지. 11(1):30-37.

2. 김원호, 서 성, 임영철, 신재순, 성병렬, 지희정, 이상진, 박태일. 2007. 호남지역 답리작에서 사료 용 총체보리 우량품종 선발. 한국초지조사료학회 지. 27(3):161-166.

3. 김종덕, 권찬호, 김종근, 김창현, 노환국, 윤영만, 
이종경. 2009. 조사료생산이용. pp 93-96.

4. 농촌진흥청, 1989. 토양분석법.

5. 서종호, 이호진, 김시주. 2000a. 헤어리베치의 추 파시기에 따른 녹비의 수량 및 질소량 변화. 한 국작물학회지. 45(6):400-404.

6. 서종호, 이호진, 허일봉, 김시주, 김충국, 조현숙. 2000b. 동계 사초호밀 및 녹비 헤어리베치 재배 에 따른 토양 질산태질소 및 옥수수 질소 흡수 량 비교. 한국초지조사료학회지. 20(3):199-206.

7. 신동은. 1999. 축종별 액상분뇨와 질소시용량이 양질조사료의 수량, 사료가치 및 토양 특성에 미 치는 영향. 서울대학교 박사학위논문.

8. 육완방, 최기춘, 안승현, 이종갑, 1999 액상발효 우분의 사용시기와 시용량이 호밀경작지토양의 NO3- 함량에 미치는 영향. 한국초지조사료학회 지, 19(2)141-146.

9. 육완방. 1992a. 가축분뇨의 이용형태가 목초의 생산성, 지력증진 및 환경오염에 미치는 영향. 동물자원연구센터 중장기 연구과제 중간보고서.

10. 육완방, $1992 \mathrm{~b}$. 초지에 대한 가축분뇨의 시용. 한 국초지조사료학회지. 12:122-126.

11. 전원태, 성기영, 이종기, 김민태, 조현숙. 2007. 밭토양에서 녹비작물 헤어리베치와 호밀의 혼파 비율이 Biomass 생산에 미치는 영향. 한국작물학 회 54(3):327-331.

12. 조익환, 윤용범, 박웅렬, 황보순, 이성훈, 이주삼. 2008. 답리작으로 호밀과 헤어리베치의 단, 혼파 재배시 우분뇨 및 화학비료의 시용에 따른 생산 성 평가. 한국초지조사료학회지. 28(4):323-330.

13. 조현숙, 서종호, 김민태, 이종기, 엄순표, 이장용, 오택근. 2005. 녹비작물 투입에 따른 토양 내 인 산함량 변화. 한국작물학회 학술발표대회 논문집 50(1):300-301.

14. 진현주 · 김정갑 · 조영무 - 곽정훈 · 신재순 - 이 혁호. 1996. 답리작 호맥재배시 가축분시용이 후 작 벼의 생육 및 수량과 미질에 미치는 영향. 한 국초지조사료학회지. 16(4):338-342.

15. 채재석, 김영두, 박태일, 박호기, 장영선. 1995. 답리작 이탈리안 라이그라스의 생육도중 청예이 용이 종자생산에 미치는 영향. 한국초지조사료학 회지. 15(2):124 -131.

16. 축산연구소. 2002. 권역별 답리작 조사료 생산체 계 확립. 농촌진흥청 2002년도 연구보고서.

17. 최기춘, 육완방, 윤창. 2008. 영년초지에서 돈분 뇨의 시용형태가 목초생산, 토양성분 및 용탈수 의 성분에 미치는 영향. 한국초지조사료학회지. 28(4):331-340.

18. AOAC. 1990. Official methods of analysis(15th ed.). Association of Offical Analytical Chemists,
Washington, DC.

19. Campbell. C.M., Schnitzer M., Stewart W.B., Biederbeck J.V.O. and Selles F. 1986. Effect of manure and fertilizer on properties of a Black Chernozem in southern Saskatchewan. Can. J. Soil Sci. 66:601-613.

20. Freeze. B.S. and Sommerfeldt T.G. 1985. Breakeven hauling distances for beef feedlot manure in southern Alberta. Can. J. Soil Sci. 65:687-693.

21. Gilley, J.E., Eghball B., Blumenthal J.M. and Baltensperger D.D. 1999. Runoff and erosion from interrill areas as affected by the aoolication of manure. Transactions of the ASEA 42(4):975-980.

22. Hariston, J.E., J.O. Sanford, D.F. Pope, and D.A. Horneck. 1987. Soybean-wheat double cropping : Implications from strew management and supplemental nitrogen. Agron. J. 79:281-286.

23. Jarvis, S.C., Sherwood, A.M. and Steenvoorden, J.H. 1987. Notrogen losses from animal manures from grazed pastures and from applied slurry. In: Van Der Meer, H.G., Unwin, R.J., Van Dijk, T.A. and Ennik G.C. (eds). Animal Manure on Grassland and Fodder Crops. Fertilizer or Waste pp. 195-212. Dordrecht, the Netherlands: Martinus Nijhoff.

24. Long, F.N.J. and Gracey, H.I. 1990. Herbage prodution and nitrogen recovery from slurry injection and fertilizer nitrogen application. Grass and Forage Science 45:77-82.

25. Seo, J.H., Lee, H.J., Hub, J.B. and Kim, S.J. 1998. Effect of hairy betch (Vicia villosa Roth) green manure on maize growth and nitrogen uptake. RDA. J. Agro-Envir. Sci. 40(1):62-68.

26. Sommerfeldt, T.G., Chang, C. and Entz, T. 1988. Long-term annual manure applications increase soil organic matter and nitrogen and decrease carbon to nitrogen ratio. Soil Sci. Soc. Am J. 52:1667-1672.

27. Sommerfeldt, T.G. and Chang, C. 1985. Changes in soil properties under annual applications of feedlot manure and different tillage practices. Soil Sci. Soc. Am J. 549:983-987.

28. Sommerfeldt, T.G. and Chang, C. 1987. Soil water properties as affected by twelve annual applications of cattle feedlot manure. Soil Sci. Soc. Am J. 51:7-9.

(접수일: 2009년 9월 18일, 수정일 1차: 2009년 9월 30일, 수정일 2차: 2009년 10월 12일, 게재확정일: 2009년 11월 5일) 